\title{
Genotypic and Phenotypic Characterization of Drug-Resistant Mycobacterium tuberculosis Isolates from Rural Districts of the Western Cape Province of South Africa
}

\author{
E. M. Streicher, ${ }^{1}$ R. M. Warren, ${ }^{1}$ C. Kewley, ${ }^{2}$ J. Simpson, ${ }^{3}$ N. Rastogi, ${ }^{4}$ \\ C. Sola, ${ }^{4}$ G. D. van der Spuy, ${ }^{1}$ P. D. van Helden, ${ }^{1}$ \\ and T. C. Victor ${ }^{1 *}$ \\ MRC Centre for Molecular and Cellular Biology, Department of Medical Biochemistry, \\ University of Stellenbosch, Tygerberg, ${ }^{1}$ Brewelskloof Hospital, Worcester, ${ }^{2}$ \\ and National Health Laboratory Services, Cape Town, ${ }^{3}$ South Africa, \\ and Institut Pasteur de Guadeloupe, Pointe à Pitre, \\ Guadeloupe, France ${ }^{4}$
}

Received 12 June 2003/Returned for modification 1 September 2003/Accepted 22 October 2003

\begin{abstract}
Genotypic and phenotypic analysis of drug-resistant Mycobacterium tuberculosis isolates from the Western Cape Province of South Africa showed that drug resistance is widespread and recently transmitted. Multidrugresistant (MDR) isolates comprise $40 \%$ of this collection, and a large pool of isoniazid monoresistance may be a future source of MDR tuberculosis.
\end{abstract}

By using genotyping methods, outbreaks of multidrug-resistant tuberculosis (MDR-TB) have been identified in hospitals, among health care workers, in prisons, and in communities $(1$, $3-5,8,11,17,21)$, thus focusing attention on MDR-TB as a major public health issue. The most-extensive MDR-TB outbreak of Beijing/W-like isolates (9) occurred in New York among 267 patients, the majority of whom were coinfected with human immunodeficiency virus. The Beijing or W-like family of Mycobacterium tuberculosis continues to be the focus of extensive investigations as such strains are widely spread throughout the world $(2,10)$, including South Africa (23) and Russia (15), where it constitutes the major family of MDR-TB isolates. There is a rising concern about the spread of MDR-TB strains from developing to developed countries. However, the bacterial population structure of resistant isolates from both developed and developing countries is not well documented. It is therefore possible that the drug-resistant Beijing/W-like strain or other MDR outbreak-associated strains are widespread but have not been recognized and reported as such. MDR-TB was first recorded in 1985 in the Western Cape Province of South Africa, but no genotype data are available from these early isolates. Although drug surveillance studies have been done in the Western Cape, they have only provided information on the drug-resistant phenotype (24).

This study describes the genotypic and phenotypic characteristics of drug-resistant isolates $(n=482)$ from 328 cases collected from Jan 2001 to Feb 2002 (14 months) from 72 clinics in the Boland-Overberg and Southern Cape-Karoo re-

\footnotetext{
* Corresponding author. Mailing address: MRC Centre for Molecular and Cellular Biology, Department of Medical Biochemistry, University of Stellenbosch, P.O. Box 19063, Tygerberg 7505, South Africa. Phone: 27-21-9389251. Fax: 27-21-9389476. E-mail: tv@sun.ac.za.
}

gions of the Western Cape Province, South Africa. The first available drug-resistant isolate of each case as determined by the indirect proportion method on Lowenstein-Jensen medium (13) was used in this study. The age of patients varied from 15 to 73 years (mean, 37 years), and $59 \%$ of patients were male. The isolates were categorized into those that were isoniazid (INH) monoresistant (48\%), MDR (40\%), and MDR with rifampin monoresistance also included (12\%). Each isolate was genotypically characterized by spoligotyping, using the internationally standardized method $(12,16)$. Sixty-nine different spoligotype patterns were identified and deposited in the international database at The Pasteur Institute of Guadeloupe (7). Of these, 34 were previously listed, while the remaining 35 types were newly added to this database. The genotypic and phenotypic data were analyzed to identify characteristics of the drug-resistant-TB epidemic in the region. The results indicate that MDR-TB forms a significant part (40\%) of the drugresistant-TB epidemic and that drug-resistant TB was spread throughout the region. MDR-TB is present in the whole area but is more prevalent in one town in the Southern Cape region. INH monoresistance is more prevalent in the Boland, Overberg, and Karoo regions but less represented in the Southern Cape region (Fig. 1). Detailed analysis of the genotypic data showed that more than $80 \%$ of the isolates can be grouped based on genotypic spoligotypes and phenotypic drug resistance patterns (Fig. 2). The numerous clusters suggest that transmission of drug-resistant strains contributes to the spread of drug-resistant TB. This may be an overestimation of the extent of transmission of drug-resistant TB in the region, as the discriminatory power of spoligotyping is less than that of IS6110 restriction fragment length polymorphism analysis (14). However, the results are similar to those of a IS6110 restriction fragment length polymorphism analysis study which showed that more than $60 \%$ of 


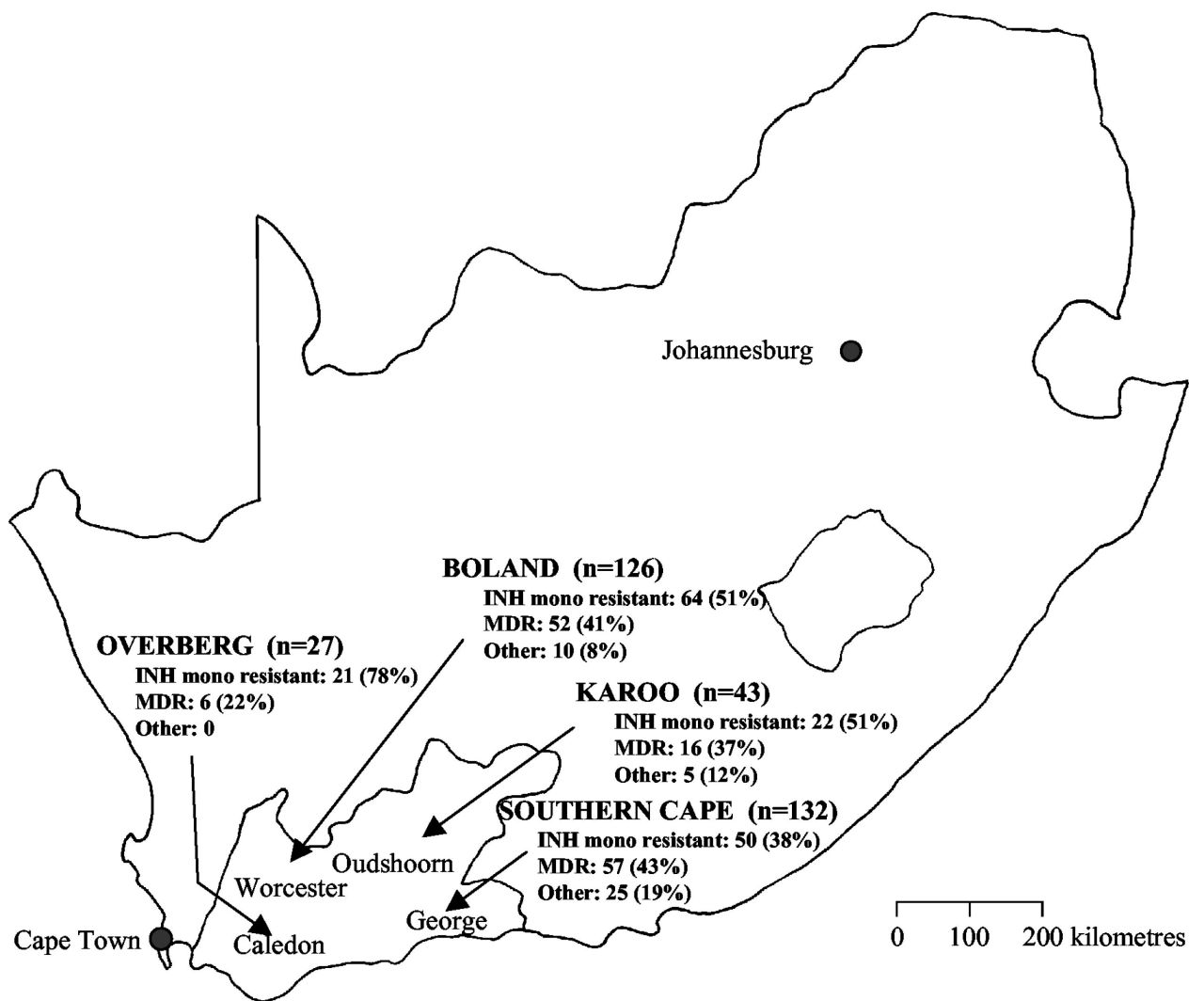

FIG. 1. Map of South Africa with the distribution of the three drug resistance groups in 72 clinics of the Western Cape Province.

drug-resistant TB occurred by transmission in urban communities in Cape Town, South Africa (22). We speculate that the high level of transmission may in part be exacerbated by the relatively slow culture-based diagnostic procedures. Application of PCR techniques for rapid diagnosis of drug resistance may help to control the ongoing transmission. Based on the spoligotype patterns, the isolates could be grouped into families (Fig. 2), and the results showed that four strain families were responsible for more than $70 \%$ of the drug-resistant-TB epidemic in the region. The Beijing/W-like and the IS6110 low-copy-number clade spoligotype patterns were the most prevalent drug-resistant isolates. It has been suggested that Beijing isolates are more frequently resistant due to their ability to mutate more rapidly than other strains (10). In neighboring communities in Cape Town, $17 \%$ of all patients with TB are infected with a Beijing strain (drug resistant or susceptible) (18). Patients infected with a Beijing/W-like drug-resistant isolate in this study may be overrepresented (28\%), suggesting that the Beijing strain family acquires drug resistance muta- tions more frequently than strain families F11 (12\%) and F28 $(5 \%)$. This is still speculative and needs further investigation. The large pool of INH-monoresistant isolates (48\%) is of great concern. INH-monoresistant isolates are mostly from the Beijing/W-like family (29\%). However, many genotypes of the INH monoresistance group are also present in the MDR group (Fig. 2), suggesting that MDR may have developed predominantly from INH-monoresistant isolates by selection. Such selection may easily result in additional MDR-TB in the future. This is supported by the observation that $20 \%$ of patients with MDR-TB in this region (since 1990) have had previous infections with monoresistant or MDR strains (C. Kewley, personal communication). Results from the present investigation showed that cases of MDR-TB are overrepresented in the IS6110 low-copy-number clade (54\%) in comparison to the results seen with the Beijing/W-like (38\%), F11 (38\%), and F28 (28\%) families. Conversely, the IS6110 low-copy-number clade underrepresents INH-monoresistant isolates (27\%). Although the IS6110 low-copy-number clade isolates are found

FIG. 2. Spoligotypes of drug-resistant isolates from two health districts of the Western Cape Province of South Africa. Explanation of footnote symbol a: Int. type, international type (according to the international database at the Pasteur Institute of Guadeloupe [7]); explanation of footnote symbol b: four strain families: Beijing/W-like (direct variable repeats 1 to 34 deleted; correlates to share type 1 in reference 20); F11 (family 11 ) (direct variable repeats 9 to 11, 21 to 24, and 33 to 36 deleted; correlates to LAM3 family in reference 6); F28 (family 28) (direct variable repeats 9, 10, and 33 to 36 deleted; correlates to the S family in reference 6); LCC (IS6110 low-copy-number clade) (direct variable repeats 18 and 33 to 36 deleted; correlates to the X family in reference 19). Abbreviations: npi, not previously identified in spoligotypes DB3 and DB4 (7, 20); npi (LT115), not previously identified in spoligotypes DB3 and DB4 (7, 20), but local type number is 115; INH mono ${ }^{\mathrm{R}}$, INH-monoresistant isolates; Multiple drug ${ }^{\mathrm{R}}$, MDR isolates (rifampin-monoresistant isolates included). 


\begin{tabular}{|c|c|c|c|c|c|}
\hline Int. type & Spoligotype pattern & $\begin{array}{c}\text { INH } \\
\text { mono }^{R}\end{array}$ & MDR & $\begin{array}{c}\text { Multiple } \\
\text { Drug }^{\mathbf{R}} \\
\end{array}$ & Family $^{b}$ \\
\hline 1 & 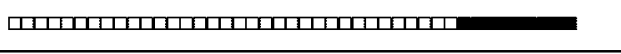 & 46 & 33 & 12 & $\begin{array}{c}\text { Beijing } \\
\mathrm{n}=91(28 \%)\end{array}$ \\
\hline npi & पात & 1 & 0 & $\mathbf{0}$ & \\
\hline npi & कात & 0 & 1 & 0 & \\
\hline npi & חדחד & 1 & 0 & $\mathbf{0}$ & \\
\hline npi & $\mathrm{CH}$ & 1 & 0 & $\mathbf{0}$ & \\
\hline npi & (1) & $\mathbf{0}$ & 1 & $\mathbf{0}$ & \\
\hline 211 & पात & 1 & 0 & $\mathbf{0}$ & F11 \\
\hline npi & חדח & 1 & 0 & 0 & $\mathrm{n}=40(12 \%)$ \\
\hline npi & تلبت & 0 & 1 & 0 & \\
\hline npi & पा & $\mathbf{0}$ & 0 & 1 & \\
\hline npi & काтापाता & $\mathbf{0}$ & 2 & $\mathbf{0}$ & \\
\hline 130 & שח & 1 & 0 & 1 & \\
\hline 33 & प्ताप & 16 & 10 & 1 & \\
\hline npi & בעם & 2 & 0 & $\mathbf{0}$ & \\
\hline 71 & (1त & 2 & 0 & 0 & \\
\hline npi & שחדחדחדי & 2 & 0 & 0 & F28 \\
\hline npi & שחדחדיחד & 1 & 1 & 0 & $n=18(5 \%)$ \\
\hline npi & मानामान & 0 & 1 & 0 & \\
\hline 34 & חाח & 4 & 3 & 2 & \\
\hline npi & יחדחחסדים & 0 & 1 & 0 & \\
\hline npi & חדחדוחד & 1 & 0 & 0 & \\
\hline 92 & חדתדוד & 9 & 2 & 1 & \\
\hline npi & שחדי & 1 & 0 & $\mathbf{0}$ & \\
\hline npi & חד & 1 & 0 & 0 & \\
\hline 348 & 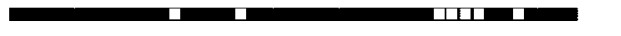 & 1 & 3 & $\mathbf{0}$ & LCC \\
\hline npi & पात & 1 & 0 & $\mathbf{0}$ & $\mathrm{n}=85(26 \%)$ \\
\hline npi & חा & 0 & 0 & 1 & \\
\hline npi (LT115) & तात & 0 & 21 & 6 & \\
\hline 137 & पात & 3 & 3 & 1 & \\
\hline 336 & 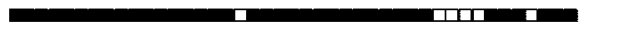 & 0 & 5 & 1 & \\
\hline 119 & 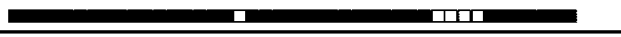 & 8 & 9 & 6 & \\
\hline 2 & 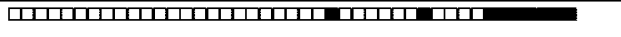 & $\mathbf{0}$ & 0 & 1 & \\
\hline npi & 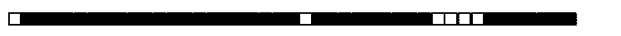 & $\mathbf{0}$ & 1 & $\mathbf{0}$ & \\
\hline npi & 110 & $\mathbf{0}$ & 1 & $\mathbf{0}$ & \\
\hline 20 & ل110 & 1 & 0 & $\mathbf{0}$ & \\
\hline npi & $\mathrm{H}$ & 1 & 0 & $\mathbf{0}$ & \\
\hline npi & פח & 2 & 0 & $\mathbf{0}$ & \\
\hline 21 & पातापाता & 1 & 0 & 0 & \\
\hline 26 & पायाता & $\mathbf{0}$ & 1 & $\mathbf{0}$ & \\
\hline npi & בחשسחד & 1 & 0 & 0 & \\
\hline npi & पा पा & 1 & 0 & $\mathbf{0}$ & \\
\hline npi & שח & 3 & 2 & 0 & \\
\hline npi & ביח & 1 & 0 & 0 & \\
\hline npi & ח & 1 & 0 & 0 & \\
\hline npi & पाताप & $\mathbf{0}$ & 1 & $\mathbf{0}$ & \\
\hline npi & 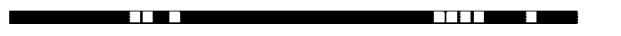 & $\mathbf{0}$ & $\mathbf{0}$ & 1 & \\
\hline npi & שחדוחדיח & 1 & 0 & 0 & \\
\hline 35 & מחדיח & 0 & 1 & 0 & \\
\hline 158 & שח & 1 & 0 & 0 & \\
\hline 766 & कानाता & 0 & 1 & 0 & Unknown \\
\hline npi & नालाप & 1 & 0 & 0 & $n=94(29 \%)$ \\
\hline npi & गातात् & 0 & 1 & 0 & \\
\hline 39 & שח חדים & 15 & 3 & $\mathbf{0}$ & \\
\hline 811 & חדיח שחיד & 1 & 1 & $\mathbf{0}$ & \\
\hline npi & חיחדיח & 2 & 4 & 2 & \\
\hline 60 & سلبت & $\mathbf{0}$ & 1 & $\mathbf{0}$ & \\
\hline 42 & تلד & 3 & 2 & 1 & \\
\hline 44 & تلبل & $\mathbf{0}$ & 3 & $\mathbf{0}$ & \\
\hline 373 & سل & 2 & 0 & 1 & \\
\hline 602 & 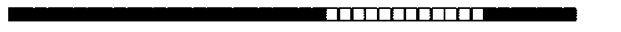 & 0 & 0 & 1 & \\
\hline 62 & 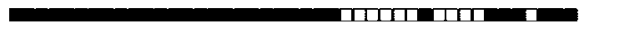 & 1 & 0 & 0 & \\
\hline 48 & בान्य & 1 & 0 & 0 & \\
\hline 237 & מחדחדחדיד & 0 & 2 & 0 & \\
\hline 50 & שיחדיח & $\mathbf{0}$ & 4 & $\mathbf{0}$ & \\
\hline 519 & שחוש & 1 & 0 & 0 & \\
\hline 521 & שחד חדים & 1 & 1 & 0 & \\
\hline 52 & שפבתח & 0 & 1 & 0 & \\
\hline 53 & मा & 8 & 3 & $\mathbf{0}$ & \\
\hline \multirow[t]{2}{*}{54} & (ب) & 3 & 0 & 0 & \\
\hline & $\begin{array}{l}\text { TOTAL } \\
\quad(\mathrm{n}=328)\end{array}$ & $\begin{array}{c}157 \\
(48 \%)\end{array}$ & $\begin{array}{c}131 \\
(40 \%)\end{array}$ & $\begin{array}{c}40 \\
(12 \%)\end{array}$ & \\
\hline
\end{tabular}


throughout the region, most of the isolates $(66 \%)$ originate from the Southern Cape. One particular spoligotype (local spoligotype 115) is unique to isolates from the largest town in the region, and this spoligotype was previously not identified in the international spoligotyping database of Guadeloupe, France (7). More than $75 \%$ of these isolates are MDR and may represent an outbreak of an emerging MDR-TB strain in this town. This study highlights the drug-resistant-TB epidemic in the Western Cape. It also raises the concern that drug resistance is transmitted and that there is a need for enhanced control strategies, which may include efficient, rapid molecular-based diagnostics.

We thank the IAEA (project SAF 6003 and RAF 6025), the NIH (grant number R21 AI 055800-01), and the Harry Crossley Foundation for financial assistance.

We thank T. Dolman and H. Pretorius for preparation of isolates and A. Jordaan for technical assistance.

\section{REFERENCES}

1. Beck-Sague, C., S. W. Dooley, M. D. Hutton, J. Otten, A. Breeden, J. T. Crawford, A. E. Pitchenik, C. Woodley, G. Cauthen, and W. R. Jarvis. 1992 Hospital outbreak of multidrug-resistant Mycobacterium tuberculosis infections. Factors in transmission to staff and HIV-infected patients. JAMA 268: $1280-1286$.

2. Bifani, P. J., B. Mathema, N. E. Kurepina, and B. N. Kreiswirth. 2002. Global dissemination of the Mycobacterium tuberculosis W-Beijing family strains. Trends Microbiol. 10:45-52.

3. Bifani, P. J., B. B. Plikaytis, V. Kapur, K. Stockbauer, X. Pan, M. L. Lutfey, S. L. Moghazeh, W. Eisner, T. M. Daniel, M. H. Kaplan, J. T. Crawford, J. M. Musser, and B. N. Kreiswirth. 1996. Origin and interstate spread of a New York City multidrug-resistant Mycobacterium tuberculosis clone family. JAMA 275:452-457.

4. Coronado, V. G., C. M. Beck-Sague, M. D. Hutton, B. J. Davis, P. Nicholas, C. Villareal, C. L. Woodley, J. O. Kilburn, J. T. Crawford, and T. R. Frieden. 1993. Transmission of multidrug-resistant Mycobacterium tuberculosis among persons with human immunodeficiency virus infection in an urban hospital: epidemiologic and restriction fragment length polymorphism analysis. J. Infect. Dis. 168:1052-1055

5. Edlin, B. R., J. I. Tokars, M. H. Grieco, J. T. Crawford, J. Williams, E. M. Sordillo, K. R. Ong, J. O. Kilburn, S. W. Dooley, and K. G. Castro. 1992. An outbreak of multidrug-resistant tuberculosis among hospitalized patients with the acquired immunodeficiency syndrome. N. Engl. J. Med. 326:1514 1521.

6. Filliol, I., J. R. Driscoll, D. van Soolingen, B. N. Kreiswirth, K. Kremer, G. Valetudie, D. D. Anh, R. Barlow, D. Banerjee, P. J. Bifani, K. Brudey, A. Cataldi, R. C. Cooksey, D. V. Cousins, J. W. Dale, O. A. Dellagostin, F. Drobniewski, G. Engelmann, S. Ferdinand, D. Gascoyne-Binzi, M. Gordon, M. C. Gutierrez, W. H. Haas, H. Heersma, G. Kallenius, E. Kassa-Kelembho, T. Koivula, H. M. Ly, A. Makristathis, C. Mammina, G. Martin, P. Mostrom, I. Mokrousov, V. Narbonne, O. Narvskaya, A. Nastasi, S. N. NiobeEyangoh, J. W. Pape, V. Rasolofo-Razanamparany, M. Ridell, M. L. Rossetti, F. Stauffer, P. N. Suffys, H. Takiff, J. Texier-Maugein, V. Vincent, J. H. de Waard, C. Sola, and N. Rastogi. 2002. Global distribution of Mycobacterium tuberculosis spoligotypes. Emerg. Infect. Dis. 8:1347-1349.

7. Filliol, I., J. R. Driscoll, D. van Soolingen, B. N. Kreiswirth, K. Kremer, G. Valetudie, D. D. Anh, R. Barlow, D. Banerjee, P. J. Bifani, K. Brudey, A. Cataldi, R. C. Cooksey, D. V. Cousins, J. W. Dale, O. A. Dellagostin, F. Drobniewski, G. Engelmann, S. Ferdinand, D. Gascoyne-Binzi, M. Gordon, M. C. Gutierrez, W. H. Haas, H. Heersma, E. Kassa-Kelembho, H. M. Ly, A. Makristathis, C. Mammina, G. Martin, P. Mostrom, I. Mokrousov, V. Narbonne, O. Narvskaya, A. Nastasi, S. N. Niobe-Eyangoh, J. W. Pape, V. Rasolofo-Razanamparany, M. Ridell, M. L. Rossetti, F. Stauffer, P. N. Suffys, H. Takiff, J. Texier-Maugein, V. Vincent, J. H. de Waard, C. Sola, and N. Rastogi. 2003. Snapshot of moving and expanding clones of Mycobacterium tuberculosis and their global distribution assessed by spoligotyping in an international study. J. Clin. Microbiol. 41:1963-1970.
8. Fischl, M. A., R. B. Uttamchandani, G. L. Daikos, R. B. Poblete, J. N. Moreno, R. R. Reyes, A. M. Boota, L. M. Thompson, T. J. Cleary, and S. Lai. 1992. An outbreak of tuberculosis caused by multiple-drug-resistant tubercle bacilli among patients with HIV infection. Ann. Intern. Med. 117:177-183.

9. Frieden, T. R., L. F. Sherman, K. L. Maw, P. I. Fujiwara, J. T. Crawford, B. Nivin, V. Sharp, D. Hewlett, Jr., K. Brudney, D. Alland, and B. N. Kreisworth. 1996. A multi-institutional outbreak of highly drug-resistant tuberculosis: epidemiology and clinical outcomes. JAMA 276:1229-1235.

10. Glynn, J. R., J. Whiteley, P. J. Bifani, K. Kremer, and D. van Soolingen. 2002. Worldwide occurrence of Beijing/W strains of Mycobacterium tuberculosis: a systematic review. Emerg. Infect. Dis. 8:843-849.

11. Jereb, J. A., R. M. Klevens, T. D. Privett, P. J. Smith, J. T. Crawford, V. L. Sharp, B. J. Davis, W. R. Jarvis, and S. W. Dooley. 1995. Tuberculosis in health care workers at a hospital with an outbreak of multidrug-resistant Mycobacterium tuberculosis. Arch. Intern. Med. 155:854-859.

12. Kamerbeek, J., L. Schouls, A. Kolk, M. van Agterveld, D. van Soolingen, S. Kuijper, A. Bunschoten, H. Molhuizen, R. Shaw, M. Goyal, and J. Van Embden. 1997. Simultaneous detection and strain differentiation of Mycobacterium tuberculosis for diagnosis and epidemiology. J. Clin. Microbiol. 35:907-914.

13. Kleeberg, H. H., Z. Blackblock, F. Boulahbal, H. L. David, H. Fink, E. M. S. Gatner, J. Grosset, J. Juhlin, J. O. Kilburn, C. G. Kleeberg, F. Mandler, S. R. Pattyn, K. F. Pererson, H. Reutgen, E. H. Runon, H. Saito, K. H. Schroder, M. F. Stander, I. Szabo, S. Takahashi, L. Tripathy, L. Tinka, and B. Vergman. 1985. A simple method of testing drug susceptibility of Mycobacterium tuberculosis: a report of an international collaborative study. Bull. Int. Union Tuberc. 60:147-150.

14. Kremer, K., D. van Soolingen, R. Frothingham, W. H. Haas, P. W. Hermans, C. Martin, P. Palittapongarnpim, B. B. Plikaytis, L. W. Riley, M. A. Yakrus, J. M. Musser, and J. D. van Embden. 1999. Comparison of methods based on different molecular epidemiological markers for typing of Mycobacterium tuberculosis complex strains: interlaboratory study of discriminatory power and reproducibility. J. Clin. Microbiol. 37:2607-2618.

15. Mokrousov, I., I. Filliol, E. Legrand, C. Sola, T. Otten, E. Vyshnevskaya, E. Limeschenko, B. Vyshnevskiy, O. Narvskaya, and N. Rastogi. 2002. Molecular characterization of multiple-drug-resistant Mycobacterium tuberculosis isolates from northwestern Russia and analysis of rifampin resistance using RNA/RNA mismatch analysis as compared to the line probe assay and sequencing of the rpoB gene. Res. Microbiol. 153:213-219.

16. Molhuizen, H. O. F., A. E. Bunschoten, L. M. Schouls, and J. D. A. Van Embden. 1998. Mycobacteria protocols: rapid detection and simultaneous strain differentiation of Mycobacterium tuberculosis complex by spoligotyping. Methods Mol. Biol. 101:381-393.

17. Pearson, M. L., J. A. Jereb, T. R. Frieden, J. T. Crawford, B. J. Davis, S. W. Dooley, and W. R. Jarvis. 1992. Nosocomial transmission of multidrugresistant Mycobacterium tuberculosis. A risk to patients and health care workers. Ann. Intern. Med. 117:191-196.

18. Richardson, M., S. W. van Lill, G. D. van der Spuy, Z. Munch, C. N. Booysen, N. Beyers, P. D. van Helden, and R. M. Warren. 2002. Historic and recent events contribute to the disease dynamics of Beijing-like Mycobacterium tuberculosis isolates in a high incidence region. Int. J. Tuberc. Lung Dis. 6:1001-1011

19. Sebban, M., I. Mokrousov, N. Rastogi, and C. Sola. 2002. A data-mining approach to spacer oligonucleotide typing of Mycobacterium tuberculosis. Bioinformatics 18:235-243.

20. Sola, C., I. Filliol, M. C. Gutierrez, I. Mokrousov, V. Vincent, and N. Rastogi. 2001. Spoligotype database of Mycobacterium tuberculosis: biogeographic distribution of shared types and epidemiologic and phylogenetic perspectives. Emerg. Infect. Dis. 7:390-396.

21. Valway, S. E., S. B. Richards, J. Kovacovich, R. B. Greifinger, J. T. Crawford, and S. W. Dooley. 1994. Outbreak of multi-drug-resistant tuberculosis in a New York State prison, 1991. Am. J. Epidemiol. 140:113-122.

22. van Rie, A., R. Warren, M. Richardson, R. P. Gie, D. A. Enarson, N. Beyers, and P. D. van Helden. 2000. Classification of drug-resistant tuberculosis in an epidemic area. Lancet 356:22-25.

23. van Rie, A., R. M. Warren, N. Beyers, R. P. Gie, C. N. Classen, M. Richardson, S. L. Sampson, T. C. Victor, and P. D. van Helden. 1999. Transmission of a multidrug-resistant Mycobacterium tuberculosis strain resembling "strain W" among noninstitutionalized, human immunodeficiency virus-seronegative patients. J. Infect. Dis. 180:1608-1615.

24. Weyer, K., P. Groenewald, M. Zwarenstein, and C. J. Lombard. 1995. Tuberculosis drug resistance in the Western Cape. S. Afr. Med. J. 85:499-504. 